Национальный медицинский исследовательский центр онкологии им. Н.Н. Блохина (Москва, Россия)

МИЕЛОИДНЫЕ СУПРЕССОРНЫЕ

КЛЕТКИ: ПРОИСХОЖДЕНИЕ,

ФЕНОТИП, ФУНКЦИИ, МЕХАНИЗМЫ

ВЗАИМОДЕЙСТВИЯ

С ИММУННЫМИ КЛЕТКАМИ

ПРИ ОПУХОЛЕВОМ РОСТЕ

Т.Н. Заботина, И.О. Панчук, Д.В. Табаков, Е.Н. Захарова

MYELOID-DERIVED SUPPRESSOR CELLS:

ORIGIN, PHENOTYPE, FUNCTIONS, MECHANISMS OF INTERACTION WITH IMMUNE CELLS DURING TUMOR GROWTH

\section{Т.Н. Заботина}

Доктор биологических наук, заведующий отделом клиниколабораторной диагностики, НИИ КО им. акад. РАН

и РАМН Н.Н. Трапезникова,

НМИЦ онкологии им. Н.Н. Блохина Минздрава России,

115478, Москва, Каширское шоссе, 24.

E-mail: tatzabotina@yandex.ru.

SPIN-код: 8628-9705.

bttps://orcid.org/0000-0001-7631-5699.

И.О. Панчук Врач,

клинико-лабораторная диагностика. E-mail:panchukio@mail.ru. SPIN-код: 7042-8465. bttps://orcid.org/0000-0002-1323-8638.

Д.В. Табаков Кандидат медищинских наук, научный сотрудник.

E-mail: dtabakov91@mail.ru. SPIN-код: 1233-6671.

bttps://orcid.org/0000-0002-1509-2206.

\section{E.H. Захарова}

Кандидат медицинских наук, научный сотрудник.

E-mail: zakbarovaen@yandex.ru. SPIN-код: 9334-0459.

bttps://orcid.org/0000-0003-2790-6673.
T.N. Zabotina

Doctor of Biological Sciences, Head of the Department of Clinical and Laboratory Diagnostics,

Trapeznikov Research Institute of Clinical Oncology of Russian Academy of Sciences and RAMS, N.N. Blokbin National Medical Research Center of Oncology,

115478, Moscow, Kashirskoe shosse, 24.

E-mail: tatzabotina@yandex.ru. SPIN code: 8628-9705. bttps://orcid.org/0000-0001-7631-5699.

I.O. Panchuk Doctor,

Clinical and Laboratory Diagnostics. E-mail:panchukio@mail.ru. SPIN code: 7042-8465. https://orcid.org/0000-0002-1323-8638.

D.V. Tabakov Candidate of Medicine, Researcher. E-mail:dtabakov91@mail.ru. SPIN code: 1233-6671. bttps://orcid.org/0000-0002-1509-2206.

E.N. Zakbarova Candidate of Medicine, Researcher. E-mail: zakbarovaen@yandex.ru. SPIN code: 9334-0459. bttps://orcid.org/0000-0003-2790-6673.

Миелоидные супрессорные клетки (МСК) представляют собой гетерогенную популяцию незрелых миелоидных клеток, функция которых заключается в ингибировании как адаптивного, так и врожденного иммунитета. При хроническом воспалении, травмах, злокачественных новообразованиях и других патологических состояниях дифференцировка миелоидных клеток идет по пути образования и накопления МСК. Повышенный интерес к изучению МСК при онкологических заболеваниях связан с их супрессорным воздействием на противоопухолевый иммунный ответ, способствующим прогрессивному росту опухоли. В обзоре приводится подробное описание происхождения МСК, их 
фенотипической гетерогенности, анализируются основные механизмы супрессорной функции МСК и их участие в подавлении противоопухолевого иммунитета, приводятся данные об основных терапевтических подходах, направленных на преодоление супрессорной функции МСК.

ключевые слова: миелоидные супрессорные клетки, иммуносупрессия, онкология, иммунотерапия, противоопухолевый иммунитет.

Myeloid-derived suppressor cells (MDSC) are a heterogeneous population of immature myeloid cells. Their function is to inhibit both adaptive and innate immunity. In chronic inflammation, injuries, malignancies, and other pathological conditions, differentiation of myeloid cells follows the path of formation and accumulation of MDSC. Increased interest in the study of MDCS in oncological diseases is associated with their suppressive effect on the antitumor immune response, which contributes to the progressive growth of the tumor. The review provides a detailed description of the origin of MDSC, their phenotypic heterogeneity, analyzes the main mechanisms of the suppressor function of MDSC and their participation in the suppression of antitumor immunity, provides data on the main therapeutic approaches aimed at overcoming the suppressor function of MDSC.

Keywords: myeloid suppressor cells, immunosuppression, oncology, immunotherapy, antitumor immunity.

\section{Введение}

$\mathrm{M}$ иелоидные супрессорные клетки (МСК) представляют собой гетерогенную популяцию незрелых миелоидных клеток, в составе которой различают несколько основных субпопуляций: моноцитарные (МО-МСК), гранулоцитарные или полиморфонуклеарные клетки (ГР-МСК), некоторые исследователи также выделяют субпопуляцию промиелоцитарных МСК (ПМ-МСК) [1]. МСК обнаружены в костном мозге, лимфатических узлах, селезенке, крови и в опухолевой ткани. Функция этих клеток заключается в ингибировании как адаптивного, так и врожденного иммунитета. Предполагается, что этот механизм является формой защиты от массивного повреждения тканей, вызванного гиперсенсибилизацией иммунной системы при неразрешенном воспалительном процессе [1-2]. Повышенный интерес к изучению МСК при онкологических заболеваниях связан с накоплением ГР-МСК и МО-МСК в опухолевом узле и их супрессорным воздействием на противоопухолевый иммунный ответ, способствующим прогрессивному росту опухоли.

\section{Дифференцировка супрессорных клеток миелоидного происхождения}

У здоровых лиц в процессе нормального гемопоэза в костном мозге миелоидные клетки-предшественники дифференцируются в моноциты, дендритные клетки и нейтрофилы. Однако при хроническом воспалении, травмах, злокачественных новообразованиях и других патологических состояниях дифференцировка миелоидных клеток может происходить по другому пути, приводящему к образованию и накоплению МСК. У здоровых людей незрелые миелоидные клетки составляют менее $1 \%$ от общего числа клеток периферической крови [3].

Созревание мононуклеарных клеток происходит в костном мозге из плюрипотентной гемопоэтической стволовой клетки. Дифференцировка в общий миелоидный предшественник происходит под воз- действием ряда колониестимулирующих факторов (КСФ). ГМ-КСФ стимулирует миелопоэз, а Г-КСФ и М-КСФ - дифференцировку гранулоцитов и макрофагов, соответственно. При онкологических заболеваниях и других патологических состояниях эти же факторы способствуют образованию МСК [4].

Классическая активация миелоидных клеток происходит при стимуляции антигенами патогенных микроорганизмов, что приводит к быстрой мобилизации моноцитов и нейтрофилов из костного мозга, синтезу провоспалительных цитокинов, увеличению экспрессии МНС II и костимулирующих молекул [5].

Патологическая активация при хроническом воспалении, опухолевом процессе, травмах и других заболеваниях приводит к тому, что образующиеся нейтрофилы и моноциты имеют незрелый фенотип, в том числе осуществляют повышенный синтез ROS, NO, ПГЕ2 и ряда других провоспалительных медиаторов.

Накопление МСК является сложным и постепенным процессом, управляемым несколькими группами факторов. Для описания процесса дифференцировки и процесса накопления МСК была предложена двухсигнальная модель (рисунок 1).

Condamine et al. утверждают, что накопление МСК требует двух различных, хотя и частично перекрывающихся, типов сигналов. Первая группа сигналов отвечает за экспансию незрелых миелоидных клеток, связанную с ингибированием их терминальной дифференцировки. Кданной группе относятся вещества, продуцируемые опухолями или стромой костного мозга в ответ на хроническую стимуляцию: факторы роста (ГМ-КСФ, М-КСФ, Г-КСФ, VEGF) и транскрипционные факторы (JAK, STAT3, STAT5, IRF8, C/EBPb, Notch). Вторая группа сигналов включает в себя провоспалительные цитокины ИНФ $\gamma$, ИЛ-1 $\beta$, ИЛ-4, ИЛ-6, ИЛ-13, ПГЕ онные факторы NF-kB, STAT1, STAT6, направляющие дифференцировку незрелых миелоидных клеток в 


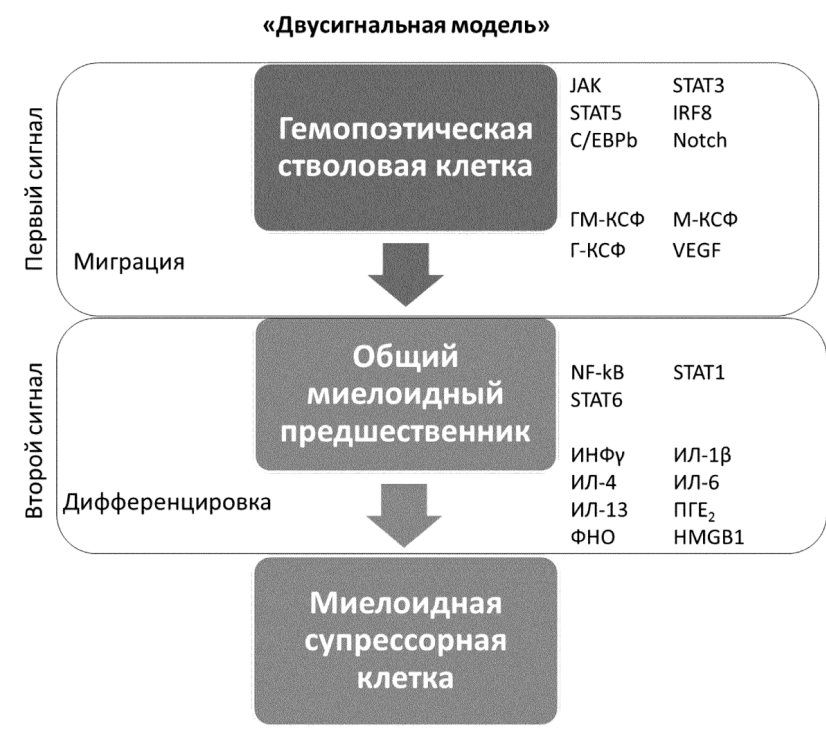

Рис. 1. Модель дифференщировки супрессорных клеток миелоидного происхождения

МСК [4] Данная двухсигнальная модель обеспечивает гибкость в регуляции этих клеток в физиологических и патологических условиях [6].

\section{Фенотип миелоидных супрессорных клеток мыши и человека}

Первые эксперименты по изучению МСК проводились на мышиных линиях. Однако характеристика этих клеток у мышей была затруднена из-за отсутствия специфических фенотипических маркеров [7]. МСК называли незрелыми миелоидными клетками (iMC), миелоидными супрессорными клетками и GR1+ миелоидными клетками до тех пор, пока в конце 1990-х годов не был предложен фенотип миелоидных клеток у мышей GR1+CD11b+. Маркер Gr1+ включает в себя определение параметров экспрессии Ly6C и Ly6G. Ly6G экспрессируется только на нейтрофилах, a Ly6C - на различных клетках, но чаще всего используется для идентификации моноцитов [8]. Было установлено, что существует клеточная популяция, которая классифицируется, как натуральные супрессорные клетки, отличные от моноцитов и нейтрофилов [9]. В 2007 году после публикации статьи Gabrilovich D.I. с соавторами был принят термин - супрессорные клетки миелоидного происхождения. В российских научных публикациях используют термин миелоидные супрессорные клетки [10].

В 2010 году идентифицированы дополнительные субпопуляции МСК мыши, характеризующиеся разной степенью экспрессии маркера GR1 и наличием маркеров F4/80 (Ly71 или EMR1 - маркер макрофагов) или МНC II [11]. Следует заметить, что эквивалент ПМ-МСК у мышей на сегодняшний день не идентифицирован. На данный момент выделяют только две субпопуляции МСК у мышей: ГР-МСК с фенотипом

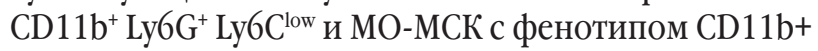
Ly6G-Ly6C high [12].

В связи с тем, что МСК - это незрелые миелоидные клетки, первоначально идентификацию этой популяции у человека проводили по экспрессии общего миелоидного маркера $\mathrm{CD} 33$ и отсутствию экспрессии маркеров, характерных для зрелых лимфоидных клеток CD3, CD19 и CD56 [1].

Однако ни один из маркеров, экспрессируемых клетками миелоидного происхождения, не является строго специфичным для МСК, и актуальным вопросом является разработка стандартных подходов идентификации и анализа данной популяции клеток.

В настоящее время используют различные комбинации поверхностных маркёров для идентификации МО-МСК, ГР-МСК и ПМ-МСК (таблица 1).

Таблища 1.

Фенотипы МСК: МО-МСК, ГР-МСК и ПМ-МСК.

\begin{tabular}{|c|c|}
\hline Фенотипы МСК & \multirow{2}{*}{$\begin{array}{c}\text { Ссылка } \\
\text { на источник литературь }\end{array}$} \\
\hline MO-МСК & \\
\hline 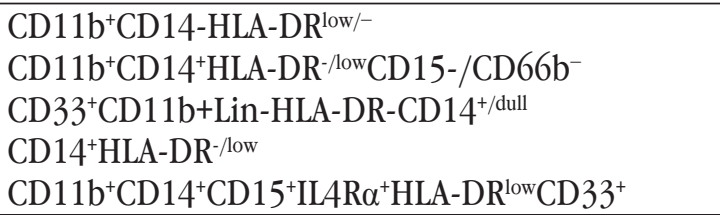 & $\begin{array}{l}{[1]} \\
{[13]} \\
{[14]} \\
{[15]} \\
{[16]}\end{array}$ \\
\hline ГР-МСК & \\
\hline 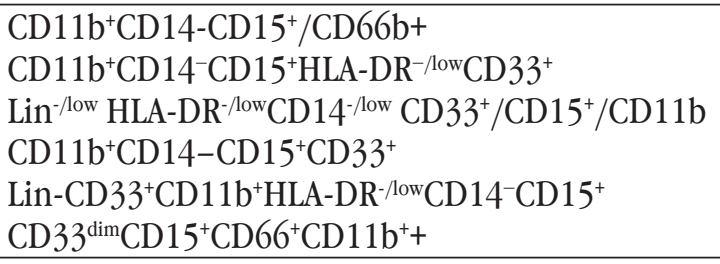 & $\begin{array}{c}{[1,13]} \\
{[17]} \\
{[18]} \\
{[19]} \\
{[14]} \\
{[13]}\end{array}$ \\
\hline ПМ-МСК & \\
\hline $\begin{array}{l}\text { Lin }^{-} \text {HLA-DR }^{-} \mathrm{CD} 33^{+} \\
\text {Lin }^{-/ \text {low }} \text { HLA-DR }^{-} \text {CD } 33^{+} / \mathrm{CD}_{11} b^{+}\end{array}$ & $\begin{array}{c}{[2]} \\
{[12]}\end{array}$ \\
\hline
\end{tabular}


Стоит отметить и тот факт, что МСК являются минорной популяцией, и для их анализа разные авторы применяют разные подходы к стратегии гейтирования [1].

\section{Механизм иммуносупрессии при участии МСК}

МСК для реализации своей функции взаимодействуют с другими клетками через поверхностные рецепторы или путем секреции растворимых медиаторов в очаге воспаления. Среди растворимых факторов основными являются: аргиназа 1 (ARG1), индуцируемая NO-синтаза (iNOS), трансформирующий ростовой фактор $\beta$ (ТРФ $\beta$ ), интерлейкин-10 (ИЛ-10), циклооксигеназа-2 (ЦОГ-2), индоломин-2, 3- диоксигеназа (ИДО). Каждый из них играет важную роль в подавлении иммунного ответа, как вместе, так и по отдельности [20].

Иммунное подавление, оказываемое МСК, связано с несколькими механизмами (рисунок 2).

Супрессорная активность МСК сопряжена с метаболизмом L-аргинина. Он служит субстратом для двух ферментов: iNOS и ARG1, которые играют важную роль в ингибировании функции Т-клеток [23].

Высокая активность фермента ARG1 в МСК приводит к усиленному катаболизму L-аргинина, превращая его в мочевину и L-орнитин, истощая запас аминокислот в микроокружении. В свою очередь, дефицит L-аргинина вызывает остановку клеточного цикла активированных Т-клеток за счет снижения проведения сигнала через $\zeta$-цепь TCR (CD247) и уменьшения экспрессии регуляторов клеточного цикла: циклина D3 и циклинзависимой киназы 4 (CDK4). Активность аргиназы-1 усиливается цитокинами ИЛ-4 или в сочетании с ИЛ-13 и ИНФ

Аргиназа-1 в сочетании с iNOS генерируют реактивные формы азота (NO), которые нитруют TCR, что приводит к супрессии Т-клеток или их апоптозу. Если количество iNOS выделяемое MCK уменышается, то они теряют свою иммунносупрессорную активность in vitro [16]. NO подавляет функцию Т-клеток через ингибирование JAK3 и STAT5, уменьшение экспрессии MHC II и индукцию апоптоза Т-клеток [26].

Показано, что снижение активности аргиназы и iNOS приводит к уменьшению нитрования тирозина и восстановлению чувствительности Т-клеток к опухолевым антигенам у больных раком предстательной железы [27].

Пероксинитрит (PNT) является продуктом химической реакции между NO и супероксидным анионом $(\mathrm{O} 2)$ и является одним из самых мощных окислителей, вырабатываемых в организме. Он вызывает нитрование и нитрозилирование аминокислот цистина, метионина, триптофана и тирозина необходимых для активации Т-клеток [37]. Увеличение пероксинитрита зарегистрировано при накоплении МСК в очагах воспаления. Кроме того группой исследователей было продемонстрировано, что выработка пероксинитрита МСК во время прямого контакта с Т-клетками приводит к нитрованию TCR и молекулы CD8 ${ }^{+}$, что делает их невосприимчивыми к антигенной специфической стимуляции [28].

Повышенная продукция активных форм кислорода (ROS) является одной из основных характеристик МСК онкологических больных. Подавление продукции ROS в МСК, полученных от мышей и пациентов с онкологическими заболеваниями, полностью блокирует супрессорный эффект этих клеток in vitro. Активные формы кислорода (ROS) воздействуют на незрелые миелоидные клетки, уменьшая их способность дифференцироваться в макрофаги и дендритные клетки и влияя на образование иммунологического синапса (нитрование TCR). Кроме того, некоторые факторы, синтезируемые опухолевыми клетками, такие как ТФР $\beta$, ИЛ-10, ИЛ-6, ИЛ-3, ГМ-КСФ и фактор роста, происходящий из тромбоцитов (PDGF) могут индуцировать выработку ROS миелоидными супрессорными клетками [29].

Обнаружено, что ГР - МСК экспрессируют большое количество ROS и низкое - NO [30]. Ввиду того, что ROS является нестабильной и активной молекулой ГР-МСК необходим тесный контакт с Т-клетками, что способствует антигенспецифическому взаимодействию с ними.

МО-МСК, в свою очередь, продуцируют большое количество NO, ARG1 и иммуносупрессорных цитокинов. Эти молекулы более стабильны, поэтому не требуется такого тесного клеточного контакта, как в случае с ROS. Поэтому, MO-МСК эффективно подавляют неспецифические ответы Т-клеток и обладают более высокой иммуносупрессорной активностью, чем ГР-МСК [20].

МСК также блокируют активацию Т-клеток путем секвестрации цистеина - аминокислоты, незаменимой для процесса пролиферации Т-клеток. В норме антигенпрезентирующие клетки (АПК) синтезируют цистеин из метионина и превращают внеклеточный цистин в цистеин. Во время антигенной презентации цистеин поглощается Т-клетками. Миелоидные супрессорные клетки не способны превращать метионин в цистеин, поэтому они полностью зависят от АПК, как источника необходимой аминокислоты, поглощая большую часть доступного цистеина из микроокружения [25].

Дополнительным механизмом иммуносупрессии является высвобождение миелоидными супрессорными клетками фермента металлопротеазы ADAM 17, который подавляет экспрессию молекулы CD62L (L-селектин), что в свою очередь ведет к нарушению миграции Т-клеток в лимфатические узлы [31].

Миелоидные супрессорные клетки способствуют миграции T-reg клеток в область воспаления посредством секреции цитокинов ИЛ-10, ТРФ $\beta$, ИНФ $\gamma$ и через CD40-CD40L-взаимодействия. В работе Pan 


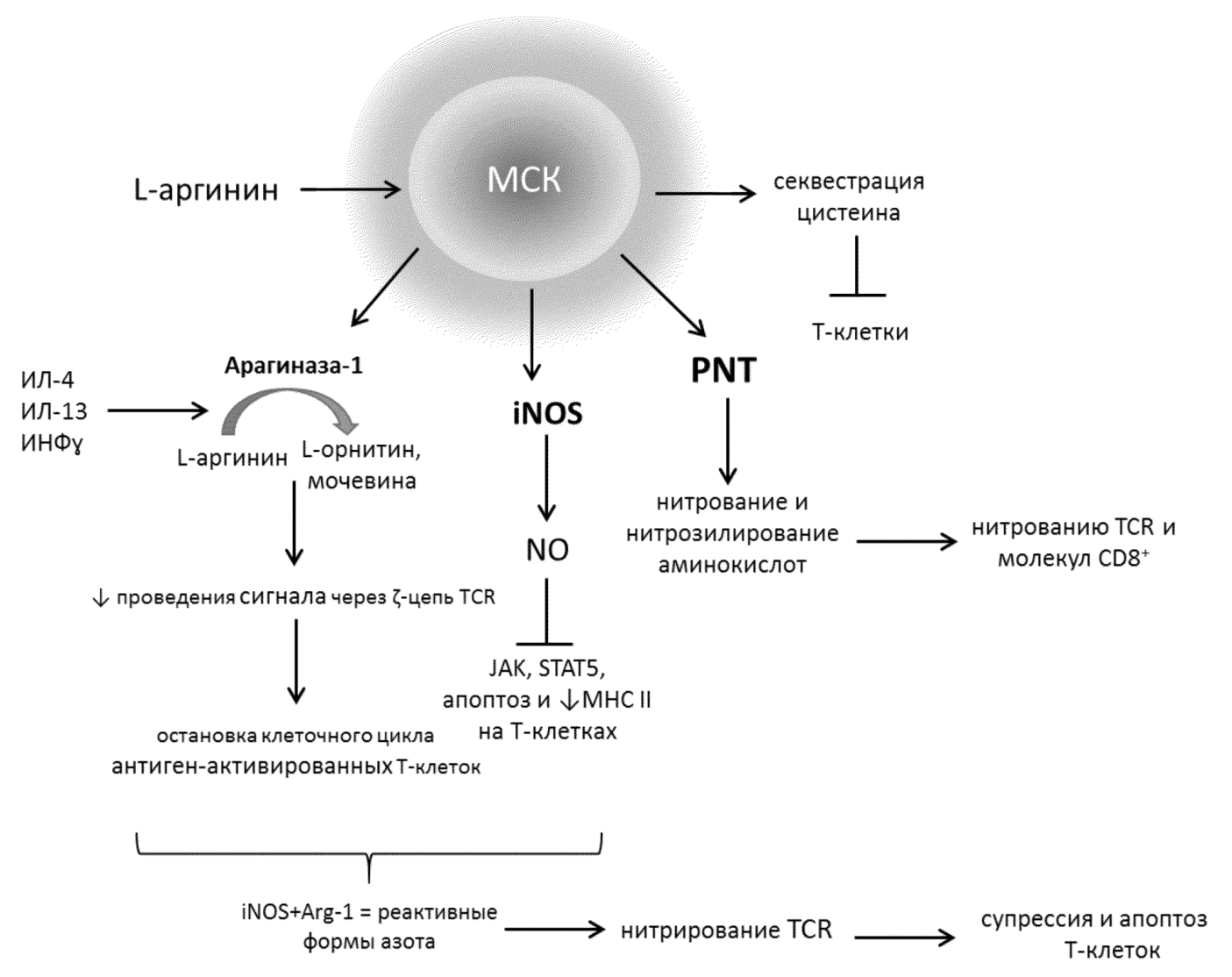

Рис. 2. Схема осуществления иммуносупрессии миелоидными супрессорными клетками

et al. показано, что CD40-дефицитные МСК не способны привлекать Treg в опухолевый узел [31,32].

Миелоидные супрессорные клетки ингибируют продукцию ИНФ $\gamma$ NK-клетками. Потеря на NK-клетах рецептора NKG2D вследствие уменьшения синтеза ИНФ $\gamma$, затрудняет активацию NK-клеток и снижает их цитотоксичность [33].

Ostrand-Rosenberg S. в 2012 году продемонстрировал, что число зрелых ДК in vitro снижается пропорционального увеличению МСК. Микроокружение опухоли (МОО), в состав которого входят МСК, вырабатывает цитокины VEGF, М-КСФ, ГМ-КСФ, ИЛ-6, ИЛ-10, также препятствующие созреванию ДК, что приводит к накоплению незрелых ДК, не способных активировать внутриопухолевые цитотоксические Т-лимфоциты и таким обзором осуществляется ускользание от иммунологического надзора $[34,35]$.

Преобладание конкретного иммуносупрессорного механизма зависит от типа МСК, стадии заболевания и локализации. При большинстве нозологических форм онкологических заболеваний (рак легких, молочной железы, толстой кишки, почек, головы и шеи, поджелудочной железы и других) в периферической крови пациентов ГР-МСК представляют собой основную популяцию миелоидных супрессорных клеток. Больные меланомой и раком предстательной железы имеют значительно более высокую долю МО-МСК в периферической крови, чем ГР-МСК. Определение соотношения между субпопуляциями ГР-МСК и МО-МСК может иметь клиническое значение в онкологической практике, поскольку эти клетки используют различные механизмы иммуносупрессии [21].

Вполне вероятно, что механизм действия МСК может меняться во время прогрессирования заболевания. Они не только оказывают влияние на иммунную систему, но и осуществляют взаимодействие с микроокружением опухоли (МОO).

\section{Взаимодействие супрессорных клеток миелоидного происхождения с микроокружением опухоли}

Исследования последних 30 лет показывают, что микроокружение является важным фактором, определяющим развитие опухоли. Микроокружение опухоли формируется на каждом этапе ее прогрессирования и имеет возможность индуцировать как неблагоприятные, так и благоприятные факторы для опухолевого генеза. Компоненты МОО включают в себя локальные стромальные клетки, такие как тканевые фибробласты, нейтрофилы и макрофаги, а также эндотелиальные, миелоидные и лимфоидные клетки, клетки-предшественники и циркулирующие тромбоциты $[21,36]$.

Среди иммунокомпетентных компонентов МОО присутствуют МСК, $\mathrm{M}_{2}$-макрофаги и Treg, преобладающие над макрофагами $\mathrm{M}_{1}$, ДК и эффекторными $\mathrm{CD}^{+}-$ и $\mathrm{CD}^{+}$- Т-лимфоцитами. Динамическое и постоянно осуществляющееся перекрестное взаимодействие 
между опухолевыми и иммунными клетками формирует аутокринную петлю обратной связи, которая поддерживает накопление МСК [42].

Классические активированные макрофаги $\mathrm{M}_{1}$ продуцируют ИЛ-12, препятствуя развитию опухоли, тогда как альтернативно активированные макрофаги М2 продуцируют ИЛ-10 и способствуют прогрессированию опухоли [36]. МСК способствуют репрограммированию макрофагов в направлении фенотипа $\mathrm{M}_{2}$, типичного для опухолеассоциированных макрофагов. Изменение баланса между ИЛ-12 и ИЛ-10 в МОО направляет Т-клеточный иммунный ответ по второму типу, уменьшает созревание ДК, поэтому их соотношение является важным фактором для осуществления Т-клеточного иммунного ответа [34].

Показано, что в селезенке мышей, несущих различные опухоли, МСК являются преобладающей популяцией миелоидных клеток, тогда как в опухолевых узлах тех же мышей преобладали ОАМ [47]. Таким образом, МОО не только влияет на функцию МСК, но также изменяет структуру созревания МО-МСК, способствуя их быстрой дифференцировке в ОАМ [46]. В настоящее время неясно, являются ли различия в соотношении ГР-МСК/МО-МСК между опухолевым узлом и селезенкой отражением предпочтительной миграции МО-МСК в опухоль, их повышенной выживаемостью или селективной потерей ГР-МСК $[48,50]$.

На мышиной модели спонтанной меланомы было показано, что МСК проникают в первичную опухоль и способствуют эпителиально-мезенхимальному переходу [37].
Проангиогенные факторы, продуцируемые МСК (VEGF), стимулируют неоваскуляризацию опухоли, в то время как матричные металлопротеазы (MMP) способствуют инвазии и метастазированию. Повреждающие молекулы, S100A8/ A9, способствуют экспансии МСК, что приводит к притоку ещё большего количества провоспалительных факторов в среду (рисунок 3) [38].

Сосудистый эндотелиальный фактор роста (VEGF) поддерживает прогрессирование опухоли путем участия в неоангиогенезе. Показано, что у больных немелкоклеточным раком легкого VEGF является хемоаттрактантом для МСК, в то время как на мышиных моделях продемонстрирована способность МСК продуцировать VEGF, способствуя прогрессированию опухоли $[54,55]$.

Провоспалительный фактор простогландин Е2 (ПГЕ2), синтезируемый опухолью и опухолевой стромой, оказывает влияние на развитие и активность МСК. ПГЕ2-липид синтезируется из арахидоновой кислоты циклооксигеназой-2 (ЦОГ $)$, который ингибирует активность цитотоксических Т-клеток и способствует росту опухоли. ПГЕ2 участвует в дифференцировке МСК из стволовых клеток костного мозга мыши in vitro за счет экспрессии на поверхности МСК


ПГЕ 2 блокируют такую дифференцировку. Увеличение синтеза ПГЕ ${ }_{2}$ изменяет поляризацию ОАМ с $\mathrm{M}_{1}$ в $\mathrm{M}_{2}$-ориентированные макрофаги, синтезирующих аргиназу, в МОО. Опухоли нарушают внутриклеточный катаболизм ПГЕ 2 в миелоидных клетках путем

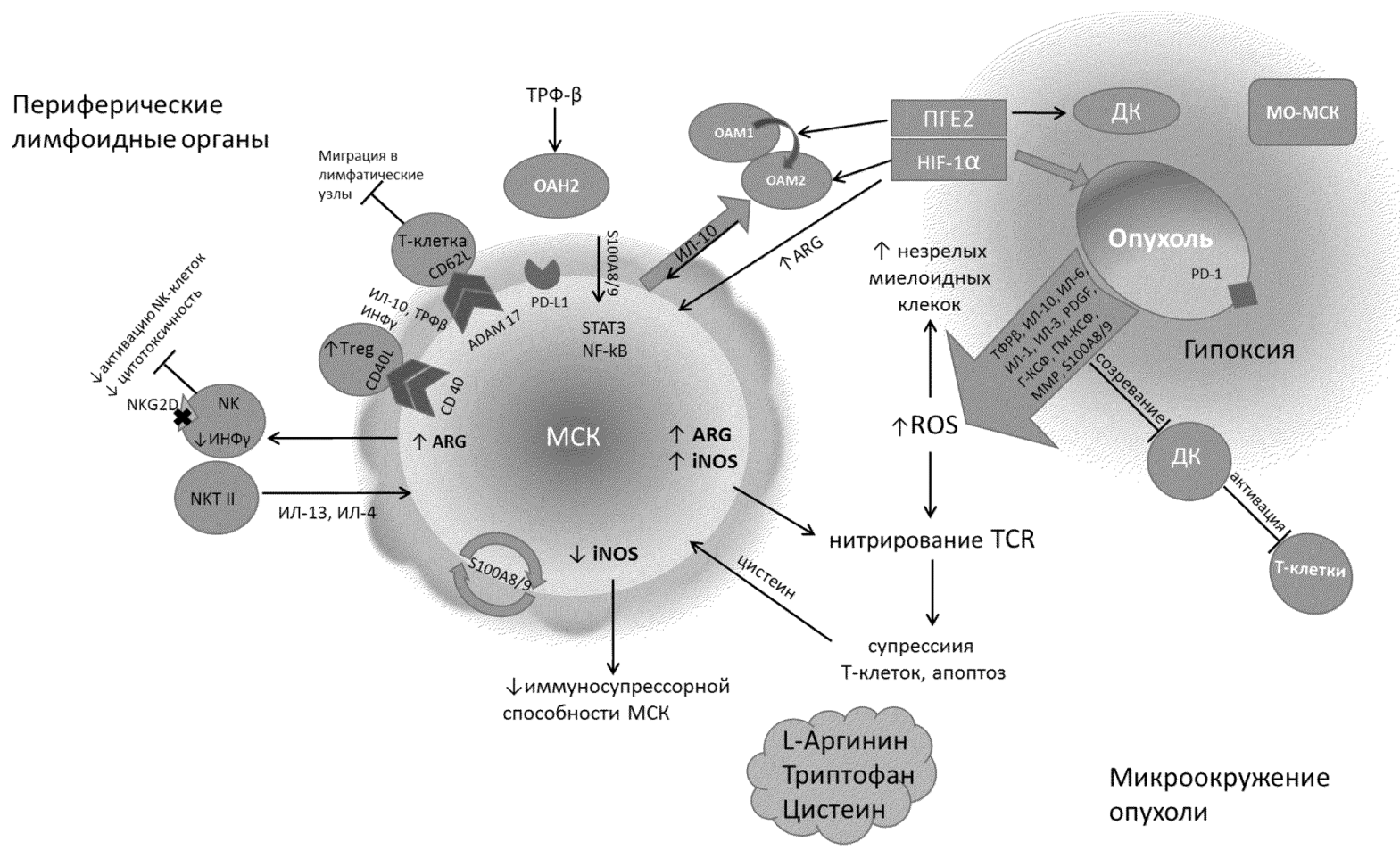

Рис. 3. Схема взаимодействия миелоидных супрессорных клеток с компонентами периферических лимфоидных органов и опухоли и её микроокружения 
одновременной стимуляции фермента, образующего $\Pi_{\Gamma} \mathrm{E}_{2}$, ЦОГ ${ }_{2}$ и ингибирования систем, разрушающих $\Pi_{2}$, что может быть также потенциальным механизмом активации МСК $[33,39]$.

Использование ингибиторов ЦОГ 2 или антагонистов рецептора ПГЕ 2 у онкологических больных приводит к нарушению цепи обратной связи ЦОГ $/ 2$ ПГЕ, уменьшает иммуносупрессию МСК и ингибирование ЦТЛ. Наличие ПГЕ 2 и ЦОГ ${ }_{2}$ на ранних стадиях развития ДК подавляет созревание моноцитов человека в функциональные ДК и трансдифференцирует ДКпредшественники в МО-МСК с полным подавлением функции ЦТЛ. ПГЕ цировке зрелых моноцитов в МСК $[21,40]$.

Провоспалительные кальций-связывающие белки S100A8 и S100A9 функционируют как гетеродимер (S100A8/A9). Они конститутивно экспрессируются в моноцитах и нейтрофилах, их экспрессия повышается при воспалении. S100A8/A9 регулируются STAT3 и NF-kB сигнальными путями, a их избыточная экспрессия приводит к увеличению МСК за счет уменьшения количества ДК и макрофагов.

Аномальная и постоянная активация STAT3 в миелоидных предшественниках предотвращает их дифференцировку в зрелые миелоидные клетки и тем самым способствует распространению МСК [38]. Продемонстрировано, что S100A8 и S100A9 белки запускают привлечение полиморфонуклеарных клеток и ГР-МСК в преметастатические ниши [41]. Миелоидные супрессорные клетки также непосредственно продуцируют S100A8/A9, что служит хемоаттрактантом для МСК, создавая положительную обратную связь [38].

HMGB1 (high mobility group box1) - негистоновый ядерный белок, который высвобождается из клеток подвергшихся некрозу, поздний медиатор воспаления. HMGB1 запускает дифференцировку МСК в костном мозге из клеток-предшественников, повышая синтез ИЛ-10, способствуя МСК-опосредованному снижению экспрессии L-селектина на наивных T-клетках и ИЛ-8 опосредованному ангиогенезу опухоли $[42,43]$.

Установлено, что для поддержки быстрой пролиферации опухолевые клетки подвергаются метаболическому сдвигу, основанному на аэробном гликолизе в качестве основного источника энергии (эффект Варбурга). Молочная кислота, которая накапливается в МОO в результате эффекта Варбурга, приводит к HIF1-опосредованной М2-подобной поляризации ОАМ и способствует развитию опухолевого фенотипа путем увеличения экспрессии VEGF, ARG1 и iNOS [21]. Опухолеассоциированная гипоксия повышает концентрацию HIF1 $\alpha$, способствуя усилению иммуносупрессорных свойств МСК, что облегчает их превращение в ОАМ, а также увеличивает экспрессию PD-L1 на поверхности опухоль-инфильтрирующих МСК. В исследовании МСК из асцитической жидкости и селезенки мышей с карциномой яичников, была по- казана связь экспрессии ARG1 и рецепторов контрольных точек иммунитета и их лигандов. Блокада либо рецепторов (PD-1, CTLA-4), либо их лигандов (PD-L1, CD80) уменьшала экспрессию ARG1 и супрессорную активность МСК [11, 44].

Блокирование экспрессии PD-L1 уменьшает МСК опосредованную Т-клеточную супрессию в условиях гипоксии. Обнаружено, что активированные Т-клетки после взаимодействия с МСК высвобождают ИЛ-10, что, в свою очередь, индуцирует фосфорилирование STAT3 в MCК и приводит к экспрессии на поверхности клеток PD-L1. Кроме того, Pinton et al. доказал, что индуцированная in vitro экспрессия лигандов PD-L1 и MHC II на МСК у пациентов с меланомой связана с повышенной экспрессией их рецепторов на Т-клетках: PD-1 и LAG-3, соответственно [44].

\section{Значение миелоидных супрессорных клеток в случаях, несвязанных с онкологией}

Уровень МСК может повышаться и при неонкологических состояниях, оказывая как положительный, так и отрицательный эффект на течение заболевания.

Продемонстрировано, что повышенное количество МСК подавляет иммунную реакцию у мышей, больных токсоплазмозом и трипаносомозом [45].

Отмечено, что повышенный уровень МСК у больных аутоиммунными заболеваниями (в том числе антиген-индуцированным аутоиммунным энтероколитом и аутоиммунным энцефаломиелитом) способствует более легкому течению болезни $[46,30]$.

Физиологические факторы, такие как стресс, возраст и беременность, влияют на уровень МСК. Например, травматический стресс у мышей сопровождается повышенным уровнем МСК в селезенке, которые подавляют пролиферацию Т-клеток (ARG1-зависимый механизм) [47].

Установлено, что уровень МСК увеличивается с возрастом. Показано, что у пациентов в возрасте от 67 до 99 лет обнаружены более высокие показатели МСК, а также повышенное содержание ИЛ-6 и ИЛ-1 $\beta$ в сыворотке $[48,49]$.

Предполагают, что снижение уровня МСК у беременных женщин может приводить к выкидышу [50]. ГР-МСК накапливаются в периферической крови беременных женщин и в пуповинной крови здоровых новорожденных. В течение нескольких дней после родов уровень МСК в крови матери возвращается к нормальному уровню [42].

Хроническое воспаление, связанное с инфекционными агентами, такими как шистосомы и H. pylori, также считается связанным с экспансией МСК. В совокупности эти данные подтверждают гипотезу о том, что хроническое воспаление способствует росту опухоли, привлекая МСК, которые обеспечивают среду, благоприятную для прогрессирования заболевания [33]. 


\section{Супрессорные клетки миелоидного происхождения, как мишень терапии}

На данный момент существует три направления подходов к терапии: устранение МСК, дезактивация МСК и уменьшение накопления МСК [51].

Подход к устранению МСК на мышиных моделях показал, что гемцитабин (подавляет синтез ДНК) истощает МСК без негативного воздействия на Т-клетки, что приводит к уменьшению роста опухоли и увеличению выживаемости, а также к повышенной чувствительности к иммунотерапии. [52].

Цисплатин (алкилирует нити ДНК) и 5-фторурацил (блокирует метилирование ДНК) преимущественно истощают субпопуляции МСК по сравнению с другими иммунными клетками, что приводит к увеличению CD8+T-лимфоцитов [53]. В 2014 году были сконструированы пептиды, полученные из S100A9, конъюгированные с Fc-фрагментами антител, способные устранить МСК в мышиных моделях [54].

Недавний клинический отчет показал, что у больных раком головы и шеи, получавших тадалафил (селективный ингибитор PDE-5, высвобождает NO) уменьшалась иммуносупрессорная активность МСК путем подавления синтеза Arg-1 и iNOS, уменьшалось количество Treg клеток, увеличивалось содержание CD8+опухолеспецифических T-клеток [55]. Лечение пациентов с почечной карциномой с помощью ATRA (понижает количество ROS, подавляет пролиферацию трансформированных клеток гемопоэза) существенно уменьшало присутствие МСК в периферической крови. Работа Musolino et al. показала, что использование ATRA уменьшало количество МСК путём дифференцировки МСК в ДК и макрофаги, и улучшало ответ на противоопухолевые вакцины [33].

В нескольких исследованиях оценивался уровень иммуносупрессии после первичной резекции опухоли у мышей, и сообщалось о частичном восстановлении функций Т-клеток. Таким образом, операция может в некоторых случаях нивелировать иммуносупрессию, тем самым поддерживая восстановление иммунной системы. Тем не менее, иммуносупрессия может повторно возникнуть при увеличении метастатических поражений и повышении количества провоспалительных цитокинов [57].

Существуют подходы к дезактивации MCK. NRF2, транскрипционный фактор, который играет важную роль в защите клеток от повреждения свободными радикалами, модулирует экспрессию нескольких антиоксидантных ферментов, которые улавливают и удаляют ROS и NO. Показано, что повышенная регуляция NRF2 синтетическими тритерпеноидами снижает продукцию ROS с помощью МСК и ослабляет их супрессорную активность ех vivo.

Уменьшение накопления МСК с помощью сунитиниба, ингибирующего проведение сигнала через STAT3, VEGF, c-kit, снижает количество МСК у пациен- тов с карциномой почек и может служить средством для поддержания противоопухолевого иммунитета.

Из-за своей иммуносупрессорной активности МСК были протестированы, как для лечения аутоиммунных заболеваний, так и для повышения толерантности иммунной системы. Например, адаптивный перенос МСК в костный мозг использовался для борьбы с последствиями реакции трансплантат против хозяина, улучшал течение экспериментального аутоиммунного энцефаломиелита, обеспечивал сохранение аллогенного трансплантата и индуцировал привлечение Treg клеток для защиты от диабета первого типа $[58,59]$.

Большое количество исследований, направленных на коррекцию уровня и активности МСК, позволит разработать терапевтические подходы для повышения эффективности иммунотерапии онкологических больных.

\section{Заключение}

Несмотря на то, что большое количество исследований позволило накопить информацию о клиническом значении МСК при различных заболеваниях, в том числе онкологических, остается ряд фундаментальных вопросов, связанных с биологией миелоидных супрессорных клеток. Ответы на эти вопросы позволят создать новые терапевтические препараты и методы лечения социально значимых заболеваний.

\section{Список сокращений}

HIF1 - Hypoxia-inducible factor 1-alpha - фактор, индуцируемый гипоксией 1-альфа.

HMGB1 - High mobility group box 1.

PNT - пероксинитрит.

Г-КСФ - гранулоцитарный колониестимулирующий фактор.

ГМ-КСФ - гранулоцитарно-макрофогальный колониестимулирующий фактор.

ГР-МСК - гранулоцитарные миелоидносупрессорные клетки.

ДК - дендритная клетка.

ИНФ $\gamma$ - интерферон - $\gamma$.

М-КСФ - макрофагальный колониестимулирующий фактор.

МО-МСК - моноцитарные миелоидно суперссорные клетки.

МОО - микроокружение опухоли.

ОАМ - опухоль ассоциированные макрофаги.

ОАН - опухоль ассоциированные нейтрофилы.

ПГЕ2 - простагландин Е2.

ПМ-МСК - промиелоцитарные миелоидно супрессорные клетки.

ТРФ $\beta$ - трансформирующий фактор роста $\beta$.

ФНО - фактор некроза опухолей.

ЦОГ2 - циклооксигеназа 2.

ЦТЛ - цитотоксические лимфоциты, 


\section{Список литературы}

1. Bronte V., Brandau S., Chen S.H., Colombo M.P., Frey A.B., Greten T.F., Mandruzzato S., Murray P.J., Ochoa A., OstrandRosenberg S., Rodriguez P.C., Sica A., Umansky V., Vonderheide R.H., Gabrilovich D.I. Recommendations for myeloidderived suppressor cell nomenclature and characterization standards// Nat Commun. - 2016. - Vol. 7 - P. 12150.

2. Gabrilovich D.I. Myeloid-Derived Suppressor Cells// Cancer Immunol Res. - 2017. - Vol. 5, No. 1. - P. 3-8.

3. Meyer C., Cagnon L., Costa-Nunes C.M., Baumgaertner P., Montandon N., Leyvraz L., Michielin O., Romano E., Speiser D.E. Frequencies of circulating MDSC correlate with clinical outcome of melanoma patients treated with ipilimumab// Cancer Immunol Immunother. - 2014. - Vol. 63, No. 3. - P. 247-57.

4. Condamine T., Gabrilovich D.I. Molecular mechanisms regulating myeloid-derived suppressor cell differentiation and function// Trends Immunol. - 2011. - Vol. 32, No. 1. - P. 19-25.

5. Kruger P., Saffarzadeb M., Weber A.N., Rieber N., Radsak M., von Bernuth H., Benarafa C., Roos D., Skokowa J., Hartl D. Neutrophils: Between host defence, immune modulation, and tissue injury// PLoS Pathog. - 2015. - Vol. 11, No. 3. - P. e1004651.

6. Condamine T., MastioJ., Gabrilovich D.I. Transcriptional regulation of myeloid-derived suppressor cells// J Leukoc Biol. - 2015. - Vol. 98, No. 6. - P. 913-22.

7. Chornoguz O., Grmai L., Sinha P., Artemenko K.A., Zubarev R.A., Ostrand-Rosenberg S. Proteomic pathway analysis reveals inflammation increases myeloid-derived suppressor cell resistance to apoptosis// Mol Cell Proteomics. 2011. - Vol. 10, No. 3. - P. M110 002980.

8. Gallina G., Dolcetti L., Serafini P., De Santo C., Marigo I., Colombo M.P., Basso G., Brombacher F., Borrello I., Zanovello P., Bicciato S., Bronte V. Tumors induce a subset of inflammatory monocytes with immunosuppressive activity on CD8+ T-cells// J Clin Invest. - 2006. - Vol. 116, No. 10. - P. 2777-90.

9. Bronte V., Wang M., Overwijk W.W., Surman D.R., Pericle F., Rosenberg S.A., Restifo N.P. Apoptotic death of CD8+ $\mathrm{T}$ lymphocytes after immunization: induction of a suppressive population of Mac-1+/Gr-1+ cells// J Immunol. 1998. - Vol. 161, No. 10. - P. 5313-20.

10. Gabrilovich D.I., Bronte V., Chen S.H., Colombo M.P., Ochoa A., Ostrand-Rosenberg S., Schreiber H. The terminology issue for myeloid-derived suppressor cells// Cancer Res. - 2007. - Vol. 67, No. 1. - P. 425; author reply 426.

11. Gabrilovich D.I., Nagaraj S. Myeloid-derived suppressor cells as regulators of the immune system// Nat Rev Immunol. - 2009. - Vol. 9, No. 3. - P. 162-74.

12. Gabrilovich D.I., Ostrand-Rosenberg S., Bronte V. Coordinated regulation of myeloid cells by tumours// Nat Rev Immunol. - 2012. - Vol. 12, No. 4. - P. 253-68.

13. Zhang W., LiJ., Qi G., Tu G., Yang C., Xu M. Myeloid-derived suppressor cells in transplantation: the dawn of cell therapy// J Transl Med. - 2018. - Vol. 16, No. 1. - P. 19.

14. Shoji H., Tada K., Kitano S., Nishimura T., Shimada Y., Nagashima K., Aoki K., Hiraoka N., Honma Y., Iwasa S., Takashima A., Kato K., Boku N., Honda K., Yamada T., Heike Y., Hamaguchi T. The peripheral immune status of granulocytic myeloid-derived suppressor cells correlates the survival in advanced gastric cancer patients receiving cisplatin-based chemotherapy// Oncotarget. - 2017. - Vol. 8, No. 56. - P. 95083-95094.

15. Filipazzi P., Valenti R., Huber V., Pilla L., Canese P., Iero M., Castelli C., Mariani L., Parmiani G., Rivoltini L. Identification of a new subset of myeloid suppressor cells in peripheral blood of melanoma patients with modulation by a granulocyte-macrophage colony-stimulation factor-based antitumor vaccine// J Clin Oncol. - 2007. - Vol. 25, No. 18. - P. 2546-53.

16. Solito S., Falisi E., Diaz-Montero C.M., Doni A., Pinton L., Rosato A., Francescato S., Basso G., Zanovello P., Onicescu G., Garrett-Mayer E., Montero A.J., Bronte V., Mandruzzato S. A human promyelocytic-like population is responsible for the immune suppression mediated by myeloid-derived suppressor cells// Blood. - 2011. - Vol. 118, No. 8. - P. 2254-65.

17.Montero A.J., Diaz-Montero C.M., Kyriakopoulos C.E., Bronte V., Mandruzzato S. Myeloid-derived suppressor cells in cancer patients: a clinical perspective// J Immunother. - 2012. - Vol. 35, No. 2. - P. 107-15.

18. Raychaudburi B., Rayman P., Ireland J., Ko J., Rini B., Borden E.C., Garcia J., Vogelbaum M.A., Finke J. Myeloidderived suppressor cell accumulation and function in patients with newly diagnosed glioblastoma// Neuro Oncol. - 2011. - Vol. 13, No. 6. - P. 591-9.

19. Marvel D., Gabrilovich D.I. Myeloid-derived suppressor cells in the tumor microenvironment: expect the unexpected// J Clin Invest. - 2015. - Vol. 125, No. 9. -P. 3356-64.

20. Corzo C.A., Cotter M.J., Cheng P., Cheng F., Kusmartsev S., Sotomayor E., Padhya T., McCaffrey T.V., McCaffrey J.C., Gabrilovich D.I. Mechanism regulating reactive oxygen species in tumor-induced myeloid-derived suppressor cells// J Immunol. - 2009. - Vol. 182, No. 9. - P. 5693-701.

21. Kuma V., Patel S., Tcyganov E., Gabrilovich D.I. The Nature of Myeloid-Derived Suppressor Cells in the Tumor Microenvironment// Trends Immunol. - 2016. - Vol. 37, No. 3. - P. 208-220.

22. Shipp C., Speigl L., Janssen N., Martens A., Pawelec G. A clinical and biological perspective of human myeloidderived suppressor cells in cancer// Cell Mol Life Sci. - 2016. - Vol. 73, No. 21. - P. 4043-61.

23. Rodriguez P.C., Ochoa A.C. Arginine regulation by myeloid derived suppressor cells and tolerance in cancer: mechanisms and therapeutic perspectives// Immunol Rev. - 2008. - Vol. 222. - P. 180-91.

24. Rodriguez P.C., Quiceno D.G., Ochoa A.C. L-arginine availability regulates T-lymphocyte cell-cycle progression// Blood. - 2007. - Vol. 109, No. 4. - P. 1568-73. 
25. Srivastava M.K., Sinha P., Clements V.K., Rodriguez P., Ostrand-Rosenberg S. Myeloid-derived suppressor cells inhibit T-cell activation by depleting cystine and cysteine// Cancer Res. - 2010. - Vol. 70, No. 1. - P. 68-77.

26. Rivoltini L., Carrabba M., Huber V., Castelli C., Novellino L., Dalerba P., Mortarini R., Arancia G., Anichini A., Fais S., Parmiani G. Immunity to cancer: attack and escape in T lymphocyte-tumor cell interaction// Immunol Rev. 2002. - Vol. 188. - P. 97-113.

27. Bronte V., Kasic T., Gri G., Gallana K., Borsellino G., Marigo I., Battistini L., Iafrate M., Prayer-Galetti T., Pagano F., Viola A. Boosting antitumor responses of T lymphocytes infiltrating human prostate cancers// J Exp Med. - 2005. Vol. 201, No. 8. - P. 1257-68.

28. Szuster-Ciesielska A., Hryciuk-Umer E., Stepulak A., Kupisz K., Kandefer-Szerszen M. Reactive oxygen species production by blood neutrophils of patients with laryngeal carcinoma and antioxidative enzyme activity in their blood// Acta Oncol. - 2004. - Vol. 43, No. 3. - P. 252-8.

29. Sauer H., Wartenberg M., Hescheler J. Reactive oxygen species as intracellular messengers during cell growth and differentiation// Cell Physiol Biochem. - 2001. - Vol. 11, No. 4. - P. 173-86.

30.Zhu B., Bando Y., Xiao S., Yang K., Anderson A.C., Kuchroo V.K., Khoury S.J. CD11b+Ly-6C(hi) suppressive monocytes in experimental autoimmune encephalomyelitis// J Immunol. - 2007. - Vol. 179, No. 8. - P. 5228-37.

31. Nagaraj S., Gabrilovich D.I. Myeloid-derived suppressor cells in human cancer// Cancer J. - 2010. - Vol. 16, No. 4. - P. 348-53.

32. Pan P.Y., Ma G., Weber K.J., Ozao-Choy J., Wang G., Yin B., Divino C.M., Chen S.H. Immune stimulatory receptor CD40 is required for T-cell suppression and T regulatory cell activation mediated by myeloid-derived suppressor cells in cancer// Cancer Res. - 2010. - Vol. 70, No. 1. - P. 99-108.

33. Musolino C., Allegra A., Pioggia G., Gangemi S. Immature myeloid-derived suppressor cells: A bridge between inflammation and cancer (Review) // Oncol Rep. - 2017. - Vol. 37, No. 2. - P. 671-683.

34. Ostrand-Rosenberg S., Sinha P., Beury D.W., Clements V.K. Cross-talk between myeloid-derived suppressor cells (MDSC), macrophages, and dendritic cells enhances tumor-induced immune suppression// Semin Cancer Biol. 2012. - Vol. 22, No. 4. - P. 275-81.

35. Gabrilovich D. Mechanisms and functional significance of tumour-induced dendritic-cell defects// Nat Rev Immunol. - 2004. - Vol. 4, No. 12. - P. 941-52.

36. Kim J., Bae J.S. Tumor-Associated Macrophages and Neutrophils in Tumor Microenvironment// Mediators Inflamm. - 2016. -P. 6058147.

37. Toh B., Wang X., Keeble J., Sim W.J., Khoo K., Wong W.C., Kato M., Prevost-Blondel A., Thiery J.P., Abastado J.P. Mesenchymal transition and dissemination of cancer cells is driven by myeloid-derived suppressor cells infiltrating the primary tumor// PLoS Biol. - 2011. - Vol. 9, No. 9. - P. e1001162.

38. Cheng P., Corzo C.A., Luetteke N., Yu B., NagarajS., Bui M.M., OrtizM., Nacken W., Sorg C., Vogl T., Roth J., Gabrilovich D.I. Inhibition of dendritic cell differentiation and accumulation of myeloid-derived suppressor cells in cancer is regulated by S100A9 protein// J Exp Med. - 2008. - Vol. 205, No. 10. - P. 2235-49.

39. Ochando J.C., Chen S.H. Myeloid-derived suppressor cells in transplantation and cancer// Immunol Res. 2012. - Vol. 54, No. 1-3. - P. 275-85.

40. Liu Y., Wei G., Cheng W.A., Dong Z., Sun H., Lee V.Y., Cha S.C., Smith D.L., Kwak L.W., Qin H. Targeting myeloid-derived suppressor cells for cancer immunotherapy// Cancer Immunol Immunother. - 2018. - Vol. 67, No. 8. - P. 1181-1195.

41. Ichikawa M., Williams R., Wang L., Vogl T., Srikrishna G. S100A8/A9 activate key genes and pathways in colon tumor progression// Mol Cancer Res. - 2011. - Vol. 9, No. 2. - P. 133-48.

42. Ostrand-Rosenberg S., Fenselau C. Myeloid-Derived Suppressor Cells: Immune-Suppressive Cells That Impair Antitumor Immunity and Are Sculpted by Their Environment// J Immunol. - 2018. - Vol. 200, No. 2. - P. 422-431.

43. Chung H.W., Lim J.B. High-mobility group box-1 contributes tumor angiogenesis under interleukin-8 mediation during gastric cancer progression// Cancer Sci. - 2017. - Vol. 108, No. 8. - P. 1594-1601.

44. Pinton L., Solito S., Damuzzo V., Francescato S., PozzuoliA., BerizziA., Mocellin S., Rossi C.R., Bronte V., Mandruzzato $S$. Activated T-cells sustain myeloid-derived suppressor cell-mediated immune suppression// Oncotarget. - 2016. Vol. 7, No. 2. - P. 1168-84.

45.Voisin M.B., Buzoni-GatelD., BoutD., Velge-Roussel F. Both expansion of regulatory GR1+CD11b+ myeloid cells and anergy of $T$ lymphocytes participate in hyporesponsiveness of the lung-associated immune system during acute toxoplasmosis// Infect Immun. - 2004. - Vol. 72, No. 9. - P. 5487-92.

46. Haile L.A., von Wasielewski R., Gamrekelashvili J., Kruger C., Bachmann O., Westendorf A.M., Buer J., Liblau R., Manns M.P., Korangy F., Greten T.F. Myeloid-derived suppressor cells in inflammatory bowel disease: a new immunoregulatory pathway// Gastroenterology. - 2008. - Vol. 135, No. 3. - P. 871-81, 881 e1-5.

47. Makarenkova V.P., Bansal V., Matta B.M., Perez L.A., Ochoa J.B. CD11b+/Gr-1+ myeloid suppressor cells cause T cell dysfunction after traumatic stress// J Immunol. - 2006. - Vol. 176, No. 4. - P. 2085-94.

48. Verschoor C.P., Johnstone J., Millar J., Dorrington M.G., Habibagahi M., Lelic A., Loeb M., Bramson J.L., Bowdish D.M. Blood CD33(+) HLA-DR(-) myeloid-derived suppressor cells are increased with age and a history of cancer// J Leukoc Biol. - 2013. - Vol. 93, No. 4. - P. 633-7.

49. Hanson E.M., Clements V.K., Sinha P., Ilkovitch D., Ostrand-Rosenberg S. Myeloid-derived suppressor cells downregulate L-selectin expression on CD4+ and CD8+ T cells// J Immunol. - 2009. - Vol. 183, No. 2. - P. 937-4. 
50. Kostlin N., Kugel H., Spring B., Leiber A., Marme A., Henes M., Rieber N., Hartl D., Poets C.F., Gille C. Granulocytic myeloid derived suppressor cells expand in human pregnancy and modulate T-cell responses// Eur J Immunol. 2014. - Vol. 44, No. 9. - P. 2582-91.

51. Wesolowski R., Markowitz J., Carson W.E. Myeloid derived suppressor cells - a new therapeutic target in the treatment of cancer// J Immunother Cancer. - 2013. - Vol. 1. - P. 10.

52. Gujar S.A., Clements D., Dielschneider R., Helson E., Marcato P., Lee P.W. Gemcitabine enhances the efficacy of reovirus-based oncotherapy through anti-tumour immunological mechanisms// Br J Cancer. - 2014. - Vol. 110, No. 1. - P. 83-93.

53. Ugel S., Peranzoni E., Desantis G., Chioda M., Walter S., Weinschenk T., Ochando J.C., Cabrelle A., Mandruzzato S., Bronte V. Immune tolerance to tumor antigens occurs in a specialized environment of the spleen// Cell Rep. 2012. - Vol. 2, No. 3. - P. 628-39.

54. Qin H., Lerman B., Sakamaki I., Wei G., Cha S.C., Rao S.S., Qian J., Hailemichael Y., Nurieva R., Dwyer K.C., Roth J., Yi Q., Overwijk W.W., Kwak L.W. Generation of a new therapeutic peptide that depletes myeloid-derived suppressor cells in tumor-bearing mice// Nat Med. - 2014. - Vol. 20, No. 6. - P. 676-81.

55. Weed D.T., Vella J.L., Reis I.M., De la Fuente A.C., Gomez C., Sargi Z., Nazarian R., Califano J., Borrello I., Serafini P. Tadalafil reduces myeloid-derived suppressor cells and regulatory T cells and promotes tumor immunity in patients with head and neck squamous cell carcinoma// Clin Cancer Res. - 2015. - Vol. 21, No. 1. - P. 39-48.

56. Predina J.D., Kapoor V., Judy B.F., Cheng G., Fridlender Z.G., Albelda S.M., Singhal S. Cytoreduction surgery reduces systemic myeloid suppressor cell populations and restores intratumoral immunotherapy effectiveness// J Hematol Oncol. - 2012. - Vol. 5. - P. 34.

57. Talmadge J.E., Gabrilovich D.I. History of myeloid-derived suppressor cells// Nat Rev Cancer. - 2013. - Vol. 13, No. 10. - P. 739-52.

58. Ioannou M., Alissafi T., Lazaridis I., Deraos G., Matsoukas J., Gravanis A., Mastorodemos V., Plaitakis A., Sharpe A., Boumpas D., Verginis $P$. Crucial role of granulocytic myeloid-derived suppressor cells in the regulation of central nervous system autoimmune disease// J Immunol. - 2012. - Vol. 188, No. 3. - P. 1136-46.

59. Chou H.S., Hsieh C.C., Charles R., Wang L., Wagner T., Fung J.J., Qian S., Lu L.L. Myeloid-derived suppressor cells protect islet transplants by B7-H1 mediated enhancement of T regulatory cells// Transplantation. - 2012. - Vol. 93 , No. 3. - P. 272-82.

\section{References}

1. Bronte V., Brandau S., Chen S.H., Colombo M.P., Frey A.B., Greten T.F., Mandruzzato S., Murray P.J., Ochoa A., Ostrand-Rosenberg S., Rodriguez P.C., Sica A., Umansky V., Vonderheide R.H., Gabrilovich D.I. Recommendations for myeloid-derived suppressor cell nomenclature and characterization standards. Nat Commun, 2016; 7: 12150. doi: $10.1038 /$ ncomms12150.

2. Gabrilovich D.I. Myeloid-Derived Suppressor Cells. Cancer Immunol Res, 2017; 5(1): 3-8. doi: 10.1158/23266066.CIR-16-0297.

3. Meyer C., Cagnon L., Costa-Nunes C.M., Baumgaertner P., Montandon N., Leyvraz L., Michielin O., Romano E., Speiser D.E. Frequencies of circulating MDSC correlate with clinical outcome of melanoma patients treated with ipilimumab. Cancer Immunol Immunother, 2014; 63(3): 247-57. doi: 10.1007/s00262-013-1508-5.

4. Condamine T., Gabrilovich D.I. Molecular mechanisms regulating myeloid-derived suppressor cell differentiation and function. Trends Immunol, 2011; 32(1): 19-25. doi: 10.1016/j.it.2010.10.002.

5. Kruger P., Saffarzadeb M., Weber A.N., Rieber N., Radsak M., von Bernuth H., Benarafa C., Roos D., Skokowa J., HartlD. Neutrophils: Between host defence, immune modulation, and tissue injury. PLoS Pathog, 2015; 11(3): e1004651. doi: 10.1371 /journal.ppat.1004651.

6. Condamine T., Mastio J., Gabrilovich D.I. Transcriptional regulation of myeloid-derived suppressor cells. J Leukoc Biol, 2015; 98(6): 913-22. doi: 10.1189/jlb.4RI0515-204R.

7. Chornoguz O., Grmai L., Sinha P., Artemenko K.A., Zubarev R.A., Ostrand-Rosenberg S. Proteomic pathway analysis reveals inflammation increases myeloid-derived suppressor cell resistance to apoptosis. Mol Cell Proteomics, 2011; 10(3): M110 002980. doi: 10.1074/mcp.M110.002980.

8. Gallina G., Dolcetti L., Serafini P., De Santo C., Marigo I., Colombo M.P., Basso G., Brombacher F., Borrello I., Zanovello $P$., Bicciato $S$., Bronte $V$. Tumors induce a subset of inflammatory monocytes with immunosuppressive activity on CD8+ T cells. J Clin Invest, 2006; 116(10): 2777-90. doi: 10.1172/JCI28828.

9. Bronte V., Wang M., Overwijk W.W., Surman D.R., Pericle F., Rosenberg S.A., Restifo N.P. Apoptotic death of CD8+ $\mathrm{T}$ lymphocytes after immunization: induction of a suppressive population of Mac-1+/Gr-1+ cells. J Immunol, 1998; 161(10): 5313-20.

10. Gabrilovich D.I., Bronte V., Chen S.H., Colombo M.P., Ochoa A., Ostrand-Rosenberg S., Schreiber H. The terminology issue for myeloid-derived suppressor cells. Cancer Res, 2007; 67(1): 425; author reply 426. doi: 10.1158/0008-5472. CAN-06-3037.

11. Gabrilovich D.I., Nagaraj S. Myeloid-derived suppressor cells as regulators of the immune system. Nat Rev Immunol, 2009; 9(3): 162-74. doi: 10.1038/nri2506.

12. Gabrilovich D.I., Ostrand-Rosenberg S., Bronte V. Coordinated regulation of myeloid cells by tumours. Nat Rev Immunol, 2012; 12(4): 253-68. doi: 10.1038/nri3175. 
13.Zhang W., LiJ., Qi G., Tu G., Yang C., Xu M. Myeloid-derived suppressor cells in transplantation: the dawn of cell therapy. J Transl Med, 2018; 16(1): 19. doi: 10.1186/s12967-018-1395-9.

14. Shoji H., Tada K., Kitano S., Nishimura T., Shimada Y., Nagashima K., Aoki K., Hiraoka N., Honma Y., Iwasa S., Takashima A., Kato K., Boku N., Honda K., Yamada T., Heike Y., Hamaguchi T. The peripheral immune status of granulocytic myeloid-derived suppressor cells correlates the survival in advanced gastric cancer patients receiving cisplatin-based chemotherapy. Oncotarget, 2017; 8(56): 95083-95094. doi: 10.18632/oncotarget.18297.

15. Filipazzi P., Valenti R., Huber V., Pilla L., Canese P., Iero M., Castelli C., Mariani L., Parmiani G., Rivoltini L. Identification of a new subset of myeloid suppressor cells in peripheral blood of melanoma patients with modulation by a granulocyte-macrophage colony-stimulation factor-based antitumor vaccine. J Clin Oncol, 2007; 25(18): 254653. doi: 10.1200/JCO.2006.08.5829.

16. Solito S., Falisi E., Diaz-Montero C.M., Doni A., Pinton L., Rosato A., Francescato S., Basso G., Zanovello P., Onicescu G., Garrett-Mayer E., Montero A.J., Bronte V., Mandruzzato S. A human promyelocytic-like population is responsible for the immune suppression mediated by myeloid-derived suppressor cells. Blood, 2011; 118(8): 2254-65. doi: 10.1182/blood-2010-12-325753.

17.Montero A.J., Diaz-Montero C.M., Kyriakopoulos C.E., Bronte V., Mandruzzato S. Myeloid-derived suppressor cells in cancer patients: a clinical perspective. J Immunother, 2012; 35(2): 107-15. doi: 10.1097/CJI.0b013e318242169f.

18. Raychaudhuri B., Rayman P., Ireland J., Ko J., Rini B., Borden E.C., Garcia J., Vogelbaum M.A., Finke J. Myeloidderived suppressor cell accumulation and function in patients with newly diagnosed glioblastoma. Neuro Oncol, 2011; 13(6): 591-9. doi: 10.1093/neuonc/nor042.

19. Marvel D., Gabrilovich D.I. Myeloid-derived suppressor cells in the tumor microenvironment: expect the unexpected. J Clin Invest, 2015; 125(9): 3356-64. doi: 10.1172/JCI80005.

20. Corzo C.A., Cotter M.J., Cheng P., Cheng F., Kusmartsev S., Sotomayor E., Padhya T., McCaffrey T.V., McCaffrey J.C., Gabrilovich D.I. Mechanism regulating reactive oxygen species in tumor-induced myeloid-derived suppressor cells. J Immunol, 2009; 182(9): 5693-701. doi: 10.4049/jimmunol.0900092.

21. Kuma V., Patel S., Tcyganov E., Gabrilovich D.I. The Nature of Myeloid-Derived Suppressor Cells in the Tumor Microenvironment. Trends Immunol, 2016; 37(3): 208-220. doi: 10.1016/j.it.2016.01.004.

22. Shipp C., Speigl L., Janssen N., Martens A., Pawelec G. A clinical and biological perspective of human myeloidderived suppressor cells in cancer. Cell Mol Life Sci, 2016; 73(21): 4043-61. doi: 10.1007/s00018-016-2278-y.

23. Rodriguez P.C., Ochoa A.C. Arginine regulation by myeloid derived suppressor cells and tolerance in cancer: mechanisms and therapeutic perspectives. Immunol Rev, 2008; 222: 180-91. doi: 10.1111/j.1600-065X.2008.00608.x.

24. Rodriguez P.C., Quiceno D.G., Ochoa A.C. L-arginine availability regulates T-lymphocyte cell-cycle progression. Blood, 2007; 109(4): 1568-73. doi: 10.1182/blood-2006-06-031856.

25. Srivastava M.K., Sinha P., Clements V.K., Rodriguez P., Ostrand-Rosenberg S. Myeloid-derived suppressor cells inhibit T-cell activation by depleting cystine and cysteine. Cancer Res, 2010; 70(1): 68-77. doi: 10.1158/0008-5472. CAN-09-2587.

26. Rivoltini L., Carrabba M., Huber V., Castelli C., Novellino L., Dalerba P., Mortarini R., Arancia G., Anichini A., Fais S., Parmiani G. Immunity to cancer: attack and escape in T lymphocyte-tumor cell interaction. Immunol Rev, 2002; 188: 97-113. doi: 10.1034/j.1600-065x.2002.18809.x.

27. Bronte V., Kasic T., Gri G., Gallana K., Borsellino G., Marigo I., Battistini L., Iafrate M., Prayer-Galetti T., Pagano F., Viola A. Boosting antitumor responses of T lymphocytes infiltrating human prostate cancers. J Exp Med, 2005; 201(8): 1257-68. doi: 10.1084/jem.20042028.

28. Szuster-Ciesielska A., Hryciuk-Umer E., Stepulak A., Kupisz K., Kandefer-Szerszen M. Reactive oxygen species production by blood neutrophils of patients with laryngeal carcinoma and antioxidative enzyme activity in their blood. Acta Oncol, 2004; 43(3): 252-8. doi: 10.1080/02841860410029708.

29. Sauer H., Wartenberg M., Hescheler J. Reactive oxygen species as intracellular messengers during cell growth and differentiation. Cell Physiol Biochem, 2001; 11(4): 173-86. doi: 10.1159/000047804.

30.Zhu B., Bando Y., Xiao S., Yang K., Anderson A.C., Kuchroo V.K., Khoury S.J. CD11b+Ly-6C(hi) suppressive monocytes in experimental autoimmune encephalomyelitis. J Immunol, 2007; 179(8): 5228-37. doi: 10.4049/jimmunol.179.8.5228.

31. Nagaraj S., Gabrilovich D.I. Myeloid-derived suppressor cells in human cancer. Cancer J, 2010; 16(4): 348-53. doi: 10.1097/PPO.0b013e3181eb3358.

32. Pan P.Y., Ma G., Weber K.J., Ozao-Choy J., Wang G., Yin B., Divino C.M., Chen S.H. Immune stimulatory receptor CD40 is required for T-cell suppression and T regulatory cell activation mediated by myeloid-derived suppressor cells in cancer. Cancer Res, 2010; 70(1): 99-108. doi: 10.1158/0008-5472.CAN-09-1882.

33. Musolino C., Allegra A., Pioggia G., Gangemi S. Immature myeloid-derived suppressor cells: A bridge between inflammation and cancer (Review). Oncol Rep, 2017; 37(2): 671-683. doi: 10.3892/or.2016.5291.

34. Ostrand-Rosenberg S., Sinha P., Beury D.W., Clements V.K. Cross-talk between myeloid-derived suppressor cells (MDSC), macrophages, and dendritic cells enhances tumor-induced immune suppression. Semin Cancer Biol, 2012; 22(4): 275-81. doi: 10.1016/j.semcancer.2012.01.011.

35. Gabrilovich D. Mechanisms and functional significance of tumour-induced dendritic-cell defects. Nat Rev Immunol, 2004; 4(12): 941-52. doi: 10.1038/nri1498.

36. Kim J., Bae J.S. Tumor-Associated Macrophages and Neutrophils in Tumor Microenvironment. Mediators Inflamm, 2016; 2016: 6058147. doi: 10.1155/2016/6058147. 
37. Toh B., Wang X., Keeble J., Sim W.J., Khoo K., Wong W.C., Kato M., Prevost-Blondel A., Thiery J.P., Abastado J.P. Mesenchymal transition and dissemination of cancer cells is driven by myeloid-derived suppressor cells infiltrating the primary tumor. PLoS Biol, 2011; 9(9): e1001162. doi: 10.1371/journal.pbio.1001162.

38. Cheng P., Corzo C.A., Luetteke N., Yu B., Nagaraj S., Bui M.M., Ortiz M., Nacken W., Sorg C., Vogl T., Roth J., Gabrilovich D.I. Inhibition of dendritic cell differentiation and accumulation of myeloid-derived suppressor cells in cancer is regulated by S100A9 protein. J Exp Med, 2008; 205(10): 2235-49. doi: 10.1084/jem.20080132.

39. Ochando J.C., Chen S.H. Myeloid-derived suppressor cells in transplantation and cancer. Immunol Res, 2012; 54(1-3): 275-85. doi: 10.1007/s12026-012-8335-1.

40. Liu Y., Wei G., Cheng W.A., Dong Z., Sun H., Lee V.Y., Cha S.C., Smith D.L., Kwak L.W., Qin H. Targeting myeloidderived suppressor cells for cancer immunotherapy. Cancer Immunol Immunother, 2018; 67(8): 1181-1195. doi: 10.1007/s00262-018-2175-3.

41. Ichikawa M., Williams R., Wang L., Vogl T., Srikrishna G. S100A8/A9 activate key genes and pathways in colon tumor progression. Mol Cancer Res, 2011; 9(2): 133-48. doi: 10.1158/1541-7786.MCR-10-0394.

42. Ostrand-Rosenberg S., Fenselau C. Myeloid-Derived Suppressor Cells: Immune-Suppressive Cells That Impair Antitumor Immunity and Are Sculpted by Their Environment. J Immunol, 2018; 200(2): 422-431. doi: 10.4049/ jimmunol.1701019.

43. Chung H.W., Lim J.B. High-mobility group box-1 contributes tumor angiogenesis under interleukin-8 mediation during gastric cancer progression. Cancer Sci, 2017; 108(8): 1594-1601. doi: 10.1111/cas.13288.

44. Pinton L., Solito S., Damuzzo V., Francescato S., Pozzuoli A., Berizzi A., Mocellin S., Rossi C.R., Bronte V., Mandruzzato $S$. Activated T cells sustain myeloid-derived suppressor cell-mediated immune suppression. Oncotarget, 2016; 7(2): 1168-84. doi: 10.18632/oncotarget.6662.

45. Voisin M.B., Buzoni-GatelD., BoutD., Velge-Roussel F. Both expansion of regulatory GR1+CD11b+ myeloid cells and anergy of $T$ lymphocytes participate in hyporesponsiveness of the lung-associated immune system during acute toxoplasmosis. Infect Immun, 2004; 72(9): 5487-92. doi: 10.1128/IAI.72.9.5487-5492.2004.

46. Haile L.A., von Wasielewski R., Gamrekelashvili J., Kruger C., Bachmann O., Westendorf A.M., Buer J., Liblau R., Manns M.P., Korangy F., Greten T.F. Myeloid-derived suppressor cells in inflammatory bowel disease: a new immunoregulatory pathway. Gastroenterology, 2008; 135(3): 871-81, 881 e1-5. doi: 10.1053/j.gastro.2008.06.032.

47. Makarenkova V.P., Bansal V., Matta B.M., Perez L.A., Ochoa J.B. CD11b+/Gr-1+ myeloid suppressor cells cause T cell dysfunction after traumatic stress. J Immunol, 2006; 176(4): 2085-94. doi: 10.4049/jimmunol.176.4.2085.

48. Verschoor C.P., Johnstone J., MillarJ., Dorrington M.G., Habibagabi M., Lelic A., Loeb M., Bramson J.L., Bowdish D.M. Blood CD33(+)HLA-DR(-) myeloid-derived suppressor cells are increased with age and a history of cancer. J Leukoc Biol, 2013; 93(4): 633-7. doi: 10.1189/jlb.0912461.

49. Hanson E.M., Clements V.K., Sinha P., Ilkovitch D., Ostrand-Rosenberg S. Myeloid-derived suppressor cells down-regulate L-selectin expression on CD4+ and CD8+ T cells. J Immunol, 2009; 183(2): 937-4. doi: 10.4049/ jimmunol.0804253.

50. Kostlin N., Kugel H., Spring B., Leiber A., Marme A., Henes M., Rieber N., Hartl D., Poets C.F., Gille C. Granulocytic myeloid derived suppressor cells expand in human pregnancy and modulate T-cell responses. Eur J Immunol, 2014; 44(9): 2582-91. doi: 10.1002/eji.201344200.

51. Wesolowski R., Markowitz J., Carson W.E. Myeloid derived suppressor cells - a new therapeutic target in the treatment of cancer. J Immunother Cancer, 2013; 1: 10. doi: 10.1186/2051-1426-1-10.

52. Gujar S.A., Clements D., Dielschneider R., Helson E., Marcato P., Lee P.W. Gemcitabine enhances the efficacy of reovirus-based oncotherapy through anti-tumour immunological mechanisms. Br J Cancer, 2014; 110(1): 83-93. doi: $10.1038 /$ bjc. 2013.695.

53. Ugel S., Peranzoni E., Desantis G., Chioda M., Walter S., Weinschenk T., Ochando J.C., Cabrelle A., Mandruzzato S., Bronte V. Immune tolerance to tumor antigens occurs in a specialized environment of the spleen. Cell Rep, 2012; 2(3): 628-39. doi: 10.1016/j.celrep.2012.08.006.

54. Qin H., Lerman B., Sakamaki I., Wei G., Cha S.C., Rao S.S., Qian J., Hailemichael Y., Nurieva R., Dwyer K.C., Roth J., Yi Q., Overwijk W.W., Kwak L.W. Generation of a new therapeutic peptide that depletes myeloid-derived suppressor cells in tumor-bearing mice. Nat Med, 2014; 20(6): 676-81. doi: 10.1038/nm.3560.

55. Weed D.T., Vella J.L., Reis I.M., De la Fuente A.C., Gomez C., Sargi Z., Nazarian R., CalifanoJ., Borrello I., Serafini P. Tadalafil reduces myeloid-derived suppressor cells and regulatory $T$ cells and promotes tumor immunity in patients with head and neck squamous cell carcinoma. Clin Cancer Res, 2015; 21(1): 39-48. doi: 10.1158/1078-0432.CCR-14-1711.

56. Predina J.D., Kapoor V., Judy B.F., Cheng G., Fridlender Z.G., Albelda S.M., Singhal S. Cytoreduction surgery reduces systemic myeloid suppressor cell populations and restores intratumoral immunotherapy effectiveness. J Hematol Oncol, 2012; 5: 34. doi: 10.1186/1756-8722-5-34.

57. Talmadge J.E., Gabrilovich D.I. History of myeloid-derived suppressor cells. Nat Rev Cancer, 2013; 13(10): 73952. doi: $10.1038 / \mathrm{nrc} 3581$.

58. Ioannou M., Alissafi T., Lazaridis I., Deraos G., Matsoukas J., Gravanis A., Mastorodemos V., Plaitakis A., Sharpe A., Boumpas D., Verginis $P$. Crucial role of granulocytic myeloid-derived suppressor cells in the regulation of central nervous system autoimmune disease. J Immunol, 2012; 188(3): 1136-46. doi: 10.4049/jimmunol.1101816.

59. Chou H.S., Hsieb C.C., Charles R., Wang L., Wagner T., Fung J.J., Qian S., Lu L.L. Myeloid-derived suppressor cells protect islet transplants by B7-H1 mediated enhancement of T regulatory cells. Transplantation, 2012; 93(3): 272-82. doi: 10.1097/TP.0b013e31823ffd39. 